\title{
KEDAULATAN TANAH BERBASIS KEARIFAN LOKAL DESA REJOAGUNG KECAMATAN SEMBORO KABUPATEN JEMBER
}

\author{
Ahmad Fadli \& A Zulkarnain Ali \\ Universitas PGRI Argopuro Jember \\ Email: fadlimangli@gmail.com \& alam.zulkarnain80@gmail.com
}

\begin{abstract}
Abstrak
Penelitian ini bertujuan untuk mengetahui adanya Keunikan kearifan lokal hukum adat sebagai salah satu bentuk cara mempertahankan Identitas dan kedaulatan tanah di desa rejoagung kecamatan semboro Kabupaten Jember, Adapun Metode yang di pakai dalam penelitian ini menggunkan metode kualitatif dengan dengan teknik triangulasi data. Hasil dari penelitian Kepemilikan dan pengelohan tanah dalam perjalanannya berkorelasi dengan adat budaya masyarakatnya, terdapat peraturan adat yang sangat dipatuhi oleh masyarakat Desa Rejoagung secara turun-temurun dalam rangka menjaga identitas sebagai desa wisata rohani dan kedaulatan tanahnya yaitu larangan agar tidak menjual tanahnya kepada penduduk luar desa, jika terpaksa dijual harus mengikuti aturan desa yang sudah diberlakukan. Larangan ini merupakan sebuah larangan yang tidak tertulis namun sangat dipatuhi dan dijalankan hingga sekarang oleh masyarakat Desa Rejoagung sehingga aturan adat tentang pertanahan di Desa Rejoagung dapat menjadi langkah preventif untuk menghindari perselisihan tanah di Indonesia. Kata Kunci: Kearifan Lokal Rejo Agung, Kedaulatan tanah
\end{abstract}

\begin{abstract}
This study aims to determine the uniqueness of local wisdom of customary law as a form of how to maintain the identity and sovereignty of the land in the village of Rejoagung, Seboro district, Jember Regency. The method used in this study uses qualitative methods with data triangulation techniques. The results of the reseach Land ownwership and management in its journey are correlated with the cultural customs of the community, there are customary regulations that are strictly obeyed by the people Rejoagung Village from generation to generation in order to maintain their identity as spiriyual tourism village and the sovereignty of their land, namely the prohibition not to sell their land to residents outside the village., if forced to be sold must follow the village rules that have been enforced. This prohibition is an unwritten prohibition but is strictly adhered to and carried outby the people of Rejoagung Village so that customary rules regarding land in Rejoagung can be preventive measure to avoid land disputes in Indonesia.
\end{abstract}

Keywords: Local Wisdom Rejoagung Village, Sovereignty of the Land

\section{PENDAHULUAN}

Pada kehidupan manusia, tanah menduduki posisi strategis dan sangat urgen. Tanah menjadi faktor kebutuhan dasar untuk menjadi tempat pijakan beraktifitas, tempat tinggal, dan sumber pangan kehidupan. Tanah menjadi salah satu sumber daya agraria yang mempunyai peran sentral dalam kehidupan manusia, baik bagi individu maupun dalam kehidupan berkelompok. Tanah tidak hanya berperan untuk bertahan hidup saja, tetapi diperlukan juga pada saat meninggal dunia sebagai tempat peristirahatan terakhir. Pada dasarnya manusia sejak lahir sampai meninggal dunia membutuhkan tanah. Tanah sebagai anugerah Tuhan, tidak ada perusahaan yang mampu memproduksinya. Sementara umat manusia dari waktu ke waktu terus mengalami peningkatan populasinya, sehingga menjadikan tanah sebagai kebutuhan dasar yang berpotensi melahirkan konflik kepentingan (Zuber, 2013).

Secara ekonomis, tanah juga mengalami peningkatan nilainya. Akhirnya banyak pemodal yang berusaha menguasai tanah untuk investasi, terlepas setelah itu dibiarkan tidak produktif. Mereka berusaha menguasai tanah sebanyak-banyaknya, 
meskipun tidak pernah memakmurkan tanah tersebut dengan cara mencangkul, membajak, menanami dan sebagainya (Hekmatyar \& Adinugraha, 2021). Fenomena reklamasi atau pengurukan pantai menjadi fenomena tersendiri yang dilakukan oleh para pengampu kepentingan untuk kepemilikan tanah (Prasetyo, Christine, \& Sudibyanung, 2020).

Tanah sebagai kebutuhan hajat hidup orang banyak, maka mengharuskan negara hadir untuk mengaturnya dengan produk hukum yang dimiliki negara tersebut (Wahidin, 2017). Bagi sebuah negara, tanah berposisi cukup strategis; pertama, tanah sebagai batas teritorial kedaulatan suatu negara. Kedua, tanah juga sebagai sarana untuk memberikan pelayanan kepada masyarakat melalui pengelolaan secara baik demi terciptanya kesejahteraan masyarakatnya. UUD 1945 memberikan penekanan secara tegas pada Pasal 33 ayat 3 bahwa; Bumi dan air dan kekayaan alam yang terkandung di dalamnya dikuasai negara dan dipergunakan sebesar-besarnya kemakmuran rakyat. Selain itu, juga terdapat UU sebagai turunan dari UUD 1945 tersebut.

Kepemilikan, penguasaan, dan pemanfaatan tanah harus benar-benar diorientasikan untuk kesejahteraan masyarakat Indonesia. Sehingga dengan demikian, kedaulatan tanah benar-benar dapat terejawantahkan dan diharapkan secara nyata. Ahmad Fadli pada tulisan opininya (Radar-Jember, 2/9/2016), menyuguhkan fakta problem di Desa Rowosari Kecamatan Sumberjambe Jember akan kepemilikan tanah yang 60\% telah dikuasai oleh orang luar desa tersebut. Demikian pula, tanah yang terletak di nol jalan nasional atau provinsi juga banyak yang dikuasi oleh kelompok pemodal tertentu saja. Realitas yang demikian melahirkan problem turunan, yakni menjadikan masyarakat terasing di kampungnya sendiri. Tanah yang dikuasai pemodal juga bisa dicermati di setiap daerah, ternyata banyak yang tidak difungsikan untuk produktif, kecuali hanya untuk aset simpanan yang didiamkan tanpa pengelolahan (Suryawan, 2021).

Mempertimbangkan unsur nilai strategis dan ekonomisnya tanah bagi segala aspek kehidupan masyarakat, maka kedaulatan tanah mutlak dalam sebuah negara. Terutama untuk Indonesia sebagai negara agraris yang sebagian besar penduduknya bergerak dalam sektor pertanian. Agar tercipta kedaulatan pangan, maka petani harus berdaya dalam memiliki, menguasai untuk menggarap lahannya. Petani jangan sampai dipisahkan dari lahan persawahan dan pekarangannya. Suatu ironi, tatkala Indonesia sebagai negara agraris dan memiliki tanah yang subur, sampai-sampai diistilahkan "tongkat bisa jadi tanaman" akan tetapi tidak memiliki kadaulatan pada bidang pangan. Faktanya kebutuhan beras dan buah nasional di Indonesia saat ini masih harus impor dari negara lain. Hal ini dapat kita pahami, salah satu problem yang dihadapi petani kita adalah adanya permasalahan penguasaan tanah garap pertanian (Wahidin, 2017).

Oleh sebab itu, penting adanya kebijakan dalam mengatur ketentuan tentang pertanahan (Adair-Toteff, 2015). Guna mengatur dan menertibkan masalah pertanahan, Indonesia memberlakukan Undang Undang Nomor 5 tahun 1960 tentang ketentuan Undang-Undang Pokok Agraria (UUPA). Secara umum UUPA mempertegas perbedaan tanah menjadi dua bagian; tanah hak dan tanah negara. Tanah hak merupakan tanah yang dibebankan suatu hak di atasnya. Tanah hak ini dikuasai oleh negara, tetapi cara penggunaannya tidak secara langsung karena ada hak dari pihak tertentu di atasnya. Sementara tanah negara merupakan tanah dalam penguasaan negara dengan tanpa adanya 
pihak lain di atas tanah tersebut (Achmad Caesar Luthful Hakim, 2021).

Kepemilikan dan pengelohan tanah dalam perjalanannya berkorelasi dengan adat budaya masyarakatnya. Seiring perkembangan kebudayaan pada masyarakat, terdapat pengaturan penguasaan tanah menggunakan budaya adat. Tanah adat berasal tanah yang pada awalnya berstatus hukum tidak tertulis, lalu berkembang dan bergelindan dengan masyarakat untuk dipatuhi dan diberlakukan pada kelompok masyarakat adat tersebut. Penguasaan dan pemanfaatan tanah melalui cara demikian, dikenal secara formal dengan sebutan hukum adat. Pada hukum adat memiliki ketentuan sebagai karakteristik uatama dalam penguasaan tanah, yakni adanya larangan memperjualbelikan tanah tersebut, meskipun tanah tersebut dalam kepemilikan pribadi.

Kepemilikan tanah pada sistem hukum adat, semua aset tanah merupakan milik bersama dalam kuasa persekutuan hukum adat. Pada hukum adat, juga terdapat kekuasaan gabungan dari persekutuan hukum adat atas tanah, bumi, dan sumber daya alam yang disebut dengan "hak ulayat". Hak ulayat menjadi landasan aturan tentang kepemilikan tanah menurut hukum adat. Jika dilihat dari keberadaan hak ulayat, maka suatu wilayah tanah bearada di bawah kekuasaan persekutuan atau kesatuan masyarakat hukum adat yang tinggal di daerah tersebut. Oleh karena itu, tanah beserta sumber daya alam yang berada di lingkup wilayah tersebut menjadi terlarang bagi yang bukan anggota persekutuan atau kesatuan masyarakat hukum adat (Hasan, Suhermi, \& Sasmiar, 2020).

Terbentuknya hukum adat merupakan perwujudan dari nilai-nilai dan kebiasaan atau tradisi yang diberlakukan secara turun-temurun. Aturan yang mentradisi tersebut menjadi tradisi hukum yang mengikat dalam wilayah tersebut dan menjadi pedoman yang mengikat di kehidupan masyarakat. Pada daerah Kabupaten Jember, terdapat sebuah desa yang memiliki aturan tentang pertanahan desa yang unik. Keunikan desa dalam pengelolahan tanah terlihat dari aturan yang mengikat masyarakatnya untuk tidak memperjualbelikan atau menyewakan tanah mereka kepada orang luar desa. Desa tersebut bernama Desa Rejoagung. Desa Rejoagung merupakan salah satu desa yang terletak di Kecamatan Semboro Kabupaten Jember. Hingga saat ini, Desa Rejoagung memiliki keunikan tersendiri berupa kearifan lokal masyarakat desa dalam menjaga kedaulatan tanahnya. Fenomena serupa juga dapat dilihat pada masyarakat hukum adat Tengger di Kabupaten Probolinggo. Hanya saja terdapat sedikit perbedaan dari latar belakang sosiokultur masyarakatnya Masyarakat Tengger merupakan masyarakat asli, sementara masyarakat Desa Rejoagung ini merupakan para masyarakat pendatang (Nurcahyono \& Astutik, 2018).

Penduduk Desa Rejoagung bukan penduduk asli, karena cikal bakal pendirinya adalah para pendatang dari desa Kertorejo dan Bongsorejo Kabupaten Jombang. Kedatangan mereka diawali dengan total 7 Kepala Keluarga pada tahun 1907. Pada saat itu mereka membuka hutan dengan mengajukan permohonan kepada pemerintah yang berkuasa (Belanda) untuk diijinkan sebagai tempat pemukiman baru. Pada tahun 1907 tersebut, surat ijin resmi diterima atas nama Marwi Kertawirya dengan luas hutan penebangan maksimal $1000 \mathrm{Ha}$.

Terdapat peraturan adat yang sangat dipatuhi oleh masyarakat Desa Rejoagung secara turun-temurun yaitu larangan agar tidak menjual tanahnya kepada penduduk luar desa, jika terpaksa dijual harus mengikuti aturan desa yang sudah diberlakukan. Larangan ini 
merupakan sebuah larangan yang tidak tertulis namun sangat dipatuhi dan dijalankan hingga sekarang oleh masyarakat Desa Rejoagung. Dengan demikian aturan adat tentang pertanahan di Desa Rejoagung dapat menjadi langkah preventif untuk menghindari perselisihan tanah di Indonesia. Mengingat bahwa konflik agraria di Indonesia hingga saat ini tidak pernah terselesaikan.

Penyebab terjadinya konflik pada bidang pertanahan di Indonesia yaitu terdapat keterbatasan persediaan tanah di suatu wilayah yang berkonflik. Konflik juga diakibatkan tumpang tindih hak milik atas tanah maupun hak pengelolaan tanah, terjadi manipulasi untuk memperoleh hak milik tanah ataupun hak kelola tanah. Selain itu, juga disebabkan oleh ketidakjelasan mengenai kedudukan hak ulayat dan masyarakat hukum adat dalam sistem perundang-undangan yang mengatur tentang agraria. Pada pasal 1 peraturan BPN (Badan Pertanahan Nasional) menyatakan bahwa kasus pertanahan adalah segketa, konflik, dan perkara pertanahan yang telah disampaikan kepada BPN RI untuk mendapatkan penanganan, penyelesaian sesuai peraturan perundang-undangan dan kebijkan pertanahan nasional. Untuk mencegah konflik agraria terus bermunculan, perlu adanya pembaruan sistem hukum yang adil serta penyelesaian konflik dilapangan harus didukung oleh lembaga pertanahan yang kuat (Suharto \& Basar, 2019).

Adapun aturan pertanahan yang diberlakukan di Desa Rejoaagung yaitu, setiap warga yang ingin menjual tanahnya harus terlebih dahulu melalui beberapa tahapan. Tahapan yang pertama yaitu menawarkan tanah tersebut ke saudara, baik itu saudara dekat maupun saudara jauh yang berdomisili di Desa Rejoagung. Kedua, menawarkan ke tetangga. Hal ini harus dilakukan jika tahapan pertama tidak terpenuhi. Apabila saudara atau tetangga tidak mampu untuk membeli tanah tersebut maka tanah tersebut ditawarkan kepada seluruh warga yang ada di Desa Rejoagung. Bapak Iswan Irianto selaku BPD Desa Rejoagung menyampaikan bahwa dengan adanya aturan adat yang sudah menjadi doktrin untuk memelihara dan mempertahankan tanah yang selalu diingatkan oleh para petinggi desa dalam beberapa kesempatan seperti; musyawarah dan kesempatan lain, sehingga masyarakat kompak dan patuh untuk memelihara budaya lokal yang sudah berjalan ratusan tahun. Setiap ada masyarakat yang akan menjual tanah, maka harus menaatai hukum adat untuk tidak menjual ke orang luar Desa Rejoagung, meskipun harganya lebih mahal.

Tanah di Desa Rejoagung ini sangat dijaga akan kedaulatan tanahnya untuk anak turun dari putra Desa Rejoagung. Upaya untuk menjaga kedaulatan tanah menggunakan pendekatan sistem kearifan. Wujud kearifan lokal berupa masyarakat tidak boleh menjual tanahnya ke luar orang Desa Rejoagung. Jika ada yang mau membeli, maka syarat utamanya harus menjadi dan tinggal di desa tersebut. Meskipun nilai jual tanah lebih murah jika dibandingkan harga umum di tetangga desa, bahkan bisa terpaut 50 sampai 70 persen jika dijual ke masyarakat luar desa, akan tetapi masyarakat desa Rejoagung tetap komitmen untuk tidak menjual ke masyarakat luar desa. Hal ini berangkat dari pemikiran pendahulu desa tersebut yang berkeyakinan jika sampai ada warga luar desa yang memiliki tanah di Desa Rejoagung, maka secara otomatis akan kehilangan identitasnya, khususnya identitas berbasis keagamaan.

Penelitian ini dilakukan dengan menitikberatkan fokus pada upaya mencipta kedaulatan tanah desa. Penelitian ini penting dilakukan karena fakta di masyarakat banyak masyarakat yang terasing di kampung halamannya sendiri, 
karena tanahnya dikuasai oleh orang luar desanya. Pencarian best practices kedaulatan tanah perlu diangkat pada ruang diskursif untuk bisa diadopsi oleh desa atau daerah lain agar ada kedaulatan tanah yang pada akhirnya diharap ada kemandirian masyarakat. Konflik tanah khususnya kasus masyarakat sekitar tambang, lebih disebabkan karena awalnya masyarakat mengabaikan makna penting kepimilikan dan penguasaan tanah untuk generasi penerus. Sebagian masyarakat terjebak pada perilaku konsumtif dan budaya instan untuk mendapatkan kesenangan sesaat, salah satunya dengan cara menjual tanahnya. Akibatnya anak turunnya tercerabut dari kepemilikan tanah untuk difungsikan sebagaimana mestinya.

\section{METODE PENELITIAN}

Metode yang digunakan dalam penelitian ini adalah metode kualitatif dengan teknik triangulasi data. Triangulasi merupakan cara yang paling umum digunakan bagi peningkatan validitas data dalam penelitian kualitatif. Dalam kaitannya dengan hal ini, dinyatakan bahwa terdapat empat macam teknik triangulasi, yaitu (1) triangulasi data/sumber (data triangulation), (2) triangulasi peneliti (investigator triangulation), (3) triangulasi metodologis (methodological triangulation), dan (4) triangulasi teoritis (theoritical triangulation). Pada dasarnya triangulasi ini merupakan teknik yang didasari pola pikir fenomenologi yang bersifat multiperspektif. Artinya untuk menarik kesimpulan yang tepat, tidak hanya menggunakan satu sudut pandang saja (Sugiyono, 2013).

Teknik pengumpulan data menggunakan teknik triagulasi yaitu dengan menggunakan beragam sumber data yang berbeda beda. Artinya data yang sama atau sejenis akan lebih mantap kebenarannya apabila digali dari beberapa sumber data yang berbeda. Oleh karena itu triangulasi data sering pula disebut sebagai triangulasi sumber.

Model penelitian triangulasi data yang mengarahkan peneliti dalam mengambil data harus menggunakan beragam sumber data yang berbeda-beda. Artinya data yang sama atau sejenis akan lebih mantap kebenarannya apabila digali dari beberapa sumber data yang berbeda. Oleh karena itu triangulasi data sering pula disebut sebagai triangulasi sumber. Teknik triangulasi sumber dapat menggunakan satu jenis sumber data misalnya informan, tetapi beberapa informan atau narasumber yang digunakan perlu diusahakan posisinya dari kelompok atau tingkatan yang berbeda-beda. Teknik triangulasi sumber dapat pula dilakukan dengan menggali informasi dari sumber-sumber data yang berbeda jenisnya, misalnya narasumber tertentu, dari kondisi tertentu, dari aktivitas yang menggambarkan perilaku orang, atau dari sumber yang berupa catatan atau arsip dan dokumen. Dalam penelitin ini Peneliti mengumpulkan data atau informasi berdasarkan sumber; wawancara dengan kepala desa, skretaris desa, BPD, LKMD dan masyarakat.

\section{HASIL PENELITIAN DAN PEMBAHASAN Hasil Penelitian}

Dalam menjabarkan penelitian ini berikut diuraikan definisi istilah untuk mempermudah pemahaman tentang arah penelitian ini. Berikut definisi istilah dari judul yang digunakan dalam penelitian ini. Definisi tersebut antara lain;

\section{Kedaulatan Tanah}

Kedualatan tanah bersinonim dengan penguasaan dan kepemilikan tanah. Penguasaan tanah secara empiris banyak melahirkan konflik. Konflik yang terbangun bisa secara vertikal, juga bisa secara horizontal. Konflik akan penguasaan tanah secara kausalitas disebabkan oleh beberapa faktor: Pertama, terjadinya pergeseran paradigmatik masyarakat komunal menjadi 
individualistik, kedua, perilaku sosialreligious yang bergeser menjadi sekulerindividualis, ketiga, pergeseran konsep pemaknaan penguasaan menjadi pemilikan. Keempat, juga terjadinya peningkatan nilai ekonomis tanah yang semakin lama semakin prestisius dan mahal (Suwitra, 2014).

Berangkat dari pertimbangan ekonomis tersebut, akhirnya terjadi penguasaan tanah oleh para pemudal. Masyarakat yang selama ini memakmurkan tanah dengan pertanian, perkebunan dan seterusnya; dipisahkan oleh kalangan pemodal dengan tanah, bahkan tanah tempat kelahirannya sendiri. Sehingga saat ini banyak masyarakat yang terasing dan menjadi buruh di kampung dan tanah kelahirannya sendiri. Masyarakat perdesaan yang selama ini telah akrab dan menjiwai dalam pengelolahan tanah, bagaimana tersadarkan akan penguasaan tanah agar tidak hanya dikuasai oleh pemodal yang dalam banayak kasus sangat eksploitatif dan tidak ramah lingkungan. Oleh karena itu, kedaulatan tanah oleh masyarakat merupakan hal mutlak yang harus diupayakan dengan mempertahankan aset kepemilikannya agar sampai anak tarun dan tidak dikuasai oleh segilintir orang saja.

\section{Kearifan Lokal}

Kearifan lokal atau local wisdom biasanya terdapat pada beberapa kelompok/masyarakat adat di Indonesia banyak mengandung nilai luhur budaya bangsa yang masih kuat menjadi identitas karakter warga masyarakatnya. Namun, di sisi lain, nilai kearifan lokal seringkali diabaikan karena dianggap tidak sesuai dengan perkembangan zamannya. Padahal dari kearifal lokal tersebut dapat dipromosikan nilai-nilai luhur yang bisa dijadikan model dalam pengembangan budaya bangsa Indonesia. Sehingga bisa dimaknai budaya kearifan lokal bisa dipahami sebuah tradisi yang didasarkan pada nilai-nilai luhur masyarakat lokal. Nilai-nilai tersebut diinternalisasikan pada kehidupan sehari-hari, sehingga bisa menjadi satu dengan budaya yang ada. Budaya yang hadir di masyarakat bukan berdasarkan hal-hal asing, tetapi didasarkan nilai-nilai yanga ada di masyarakat (Sari \& Zuber, 2020).

Kepemilikan dan pengelohan tanah dalam perjalanannya berkorelasi dengan adat budaya masyarakatnya. Sehubungan berkembangnya kebudayaan masyarakat, terdapat pengaturan penguasaan tanah sacara budaya adat. Tanah yang pada awalnya ditemukan dalam bentuk hukum tidak tertulis dan berkembang bersama masyarakat serta dipatuhi untuk diberlakukan pada kelompok masyarakat tersebut. Peraturan ini dikenal dengan sebutan hukum adat atau aturan adat tentang penguasaan tanah. Hukum adat terdapat salah satu karakteristik pokok bentuk penguasaan tanah menurut hukum adat, yaitu larangan untuk memperjualbelikan tanah meskipun tanah tersebut sudah dimiliki secara pribadi.

Pada hukum adat, tanah merupakan suatu kepemilikan bersama yang berada di bawah kekuasaan persekutuan hukum adat. Pada hukum adat terdapat kekuasaan gabungan dari persekutuan hukum adat atas tanah, bumi, dan sumber daya alam yang disebut dengan "hak ulayat". Hak ulayat menjadi landasan aturan tentang kepemilikan tanah menurut hukum adat. Jika dilihat dari keberadaan hak ulayat, maka suatu wilayah tanah bearada di bawah kekuasaan persekutuan atau kesatuan masyarakat hukum adat yang tinggal di daerah tersebut. Oleh karena itu, tanah beserta sumber daya alam yang berada di lingkup wilayah tersebut menjadi terlarang bagi yang bukan anggota persekutuan atau kesatuan masyarakat hukum adat (Ismi, 2012). 
Terbentuknya hukum adat merupakan perwujudan dari nilai-nilai dan kebiasaan atau tradisi yang diberlakukan secara turun-temurun. Aturan yang mentradisi tersebut menjadi tradisi hukum yang mengikat dalam wilayah tersebut dan menjadi pedoman yang mengikat di kehidupan masyarakat. Pada daerah Kabupaten Jember, terdapat sebuah desa yang memiliki aturan tentang pertanahan desa yang unik. Keunikan desa dalam pengelolahan tanah terlihat dari aturan yang mengikat masyarakatnya untuk tidak memperjualbelikan atau menyewakan tanah mereka kepada orang luar desa. Desa tersebut bernama Desa Rejoagung. Desa Rejoagung merupakan salah satu desa yang terletak di Tanggul bagian Selatan dan masuk Kecamatan Semboro Kabupaten Jember. Hingga saat ini, Desa Rejoagung memiliki keunikan tersendiri berupa kearifan lokal masyarakat desa dalam menjaga kedaulatan tanahnya. Dibandingkan dengan kasus serupa, misalnya pada masyarakat hukum adat Tengger di Kabupaten Probolinggo yang notabennya merupakan penduduk asli, namun di Desa Rejoagung ini merupakan para penduduk pendatang.

\section{Pembahasan \\ Kearifan Kadaulatan Tanah Desa Rejoagung}

Penduduk Desa Rejoagung bukan penduduk asli, karena cikal bakal pendirinya adalah para pendatang dari desa Kertorejo dan Bongsorejo Kabupaten Jombang. Kedatangan mereka diawali dengan total 7 Kepala Keluarga pada tahun 1907. Pada saat itu mereka membuka hutan dengan mengajukan permohonan kepada pemerintah yang berkuasa (Belanda) untuk diijinkan sebagai tempat pemukiman baru. Pada tahun 1907 tersebut, surat ijin resmi diterima atas nama Marwi Kertawirya dengan luas hutan penebangan maksimal 1000 Ha. Terdapat peraturan adat yang sangat dipatuhi oleh masyarakat Desa Rejoagung secara turun-temurun yaitu larangan agar tidak menjual tanahnya kepada penduduk luar desa, jika terpaksa dijual harus mengikuti aturan desa yang sudah diberlakukan. Larangan ini merupakan sebuah larangan yang tidak tertulis namun sangat dipatuhi dan dijalankan hingga sekarang oleh masyarakat Desa Rejoagung. Dengan demikian aturan adat tentang pertanahan di Desa Rejoagung dapat menjadi langkah preventif untuk menghindari perselisihan tanah di Indonesia. Mengingat bahwa konflik agraria di Indonesia hingga saat ini tidak pernah terselesaikan (Zuber, 2019).

Penyebab terjadinya konflik pada bidang pertanahan di Indonesia yaitu terdapat keterbatasan persediaan tanah di suatu wilayah yang berkonflik, tumpang tindih hak milik atas tanah maupun hak pengelolaan tanah, terjadi manipulasi untuk memperoleh hak milik tanah ataupun hak kelola tanah, serta ketidakjelasan mengenai kedudukan hak ulayat dan masyarakat hukum adat dalam sistem perundang undangan yang mengatur tentang agraria. Pada pasal 1 peraturan BPN (Badan Pertanahan Nasional) menyatakan bahwa kasus pertanahan adalah segketa, konflik, dan perkara pertanahan yang telah disampaikan kepada BPN RI untuk mendapatkan penanganan, penyelesaian sesuai peraturan perundang-undangan dan kebijkan pertanahan nasional. Untuk mencegah konflik agraria terus bermunculan, perlu adanya pembaruan sistem hukum yang adil serta penyelesaian konflik dilapangan harus didukung oleh lembaga pertanahan yang kuat.

Adapun aturan pertanahan yang diberlakukan di Desa Rejoaagung yaitu, setiap warga yang ingin menjual tanahnya harus terlebih dahulu melalui beberapa tahapan. Tahapan yang pertama yaitu menawarkan tanah tersebut ke saudara kandung, kemudian saudara yang agak jauh. 
Jika dari saudara tidak ada yang membeli, maka penjual tanah baru menawarkan ke tetangga. Apabila saudara atau tetangga tidak ada yang membeli tanah juga, maka tanah tersebut ditawarkan kepada seluruh warga yang ada di Desa Rejoagung tersebut. PLt Kepala Desa Rejoagung, Alrianto Adi menyampaikan informasi bahwa Jual beli tanah di Desa Rejoagung ini diikat oleh aturan hukum adat. Aturan yang ada memang tidak tertulis, tapi telah berjalan efektif di masyarakat. Masyarakat dalam menjual tanah, maka harus metawarkan ke saudara terlebih dahulu, kemudian ditawarkan ke tetanggga, jika tidak ada yang membeli baru di tawarkan ke seluruh masyarakat Desa Rejoagung. Ketentuan seperti ini sudah menjadi kesadaran kolektif masyarakat Desa Rejoagung. Memang ada masyarakat di luar Desa Rejoagung yang memiliki aset tanah di sini, akan tetapi yang bersangkutan kelahiran desa ini, hanya menikah dapat suami luar desa dan dibawah ke rumah suaminya.

Sutarmanu selaku sekretaris Desa Rejoagung menambahkan, bahwa penguatan kearifan lokal dalam mencipta kedaulatan tanah di Desa Rejoagung tersebut benar-benar terjaga lintas generasi. Mindset terbangun sejak nenek moyang yang dipertahankan sampai saat ini dengan disimbolkan adanya patung tujuh tokoh yang membabat desa tersebut sejak tahun 1907 di halaman balai desa. Harapan masyarakat Desa Rejoagung agar ganerasi penerus tidak terusir dari desanya karena adanya kekuatan pemodal. Bukannya melarang atau tidak boleh menjual tanah ke masyarakat luar desa, tetapi ini upaya agar hasil tanah dapat difungsikan, dimanfaatkan dan dinikmati oleh generasi anak cucu. Kalau ada orang luar desa yang mau memiliki tanah di Desa Rejoagung, maka ia harus tinggal di desa ini.

Alrianto sebagai ASN Pemkab Jember yang juga menjadi PLt. Kepala Desa Rejoagung menambahkan informasi dengan memberikan penuturan bahwa masyarakat Desa Rejoagung mayoritas berprofesi sebagai petani. Perilaku petani di Desa Rejoagung, mereka istitahat tidak menggarap dan perkebunan di hari Minggu. Hari Minggu sebagai hari istirahat untuk ibadah dan keluarga. Mereka bisa seperti itu, karena aset tanah sebagai lahan bekerjanya merupakan miliknya sendiri bukan menjadi buruh orang lain. Oleh karena itu mindset yang telah mentradisi dan menjadi hukum adat harus dipertahankan.

Kearifan lokal berupa hukum adat Desa Rejoagung merupakan serpihan contoh best practices desa dalam mencipta kedaulatan tanah. Masyarakat perdesaan perlu membangun kesadaran akan pentingnya membangun kepedulian mewariskan tanah untuk anak cucu. Kepedulian tokoh yang membabat Desa Rejoagung yang disebarkan menjadi kesadaran bersama dan diwariskan lintas generasi menjadi entrypoint positif. Terlepas pendekatan yang digunakan; apakah berbasis keagamaan, budaya, pendidikan, atau perdes, hal tersebut perlu diadopsi oleh desa dan daerah lain. Desa Rejoagung tentunya bisa dijadikan benchmarking agar tanah tidak hanya dikuasai segelintir pemodal saja dan untuk dijadikan langkah preventif meminimalisir konflik kepentingan tanah.

\section{KESIMPULAN}

Eksistensi tanah menduduki fungsi strategis dalam kehidupan umat manusia. Secara kausalitas menusia memiliki ketergantungan terhadap tanah, sementara tanah tidak bisa diproduksi kecuali diadakannya reklamasi. Beberapa faktor seperti; Pergeseran paradigmatik masyarakat dari komunal menjadi individualistik, sosial-religiousjadi sekulerindividualis, dan percepatan nilai ekonomis tanah yang semakin mahal, menjadikan tanah sebagai alat perebutan yang 
melahirkan banyak konflik. Korban dari adanya itu semua justeru masyarakat umum yang memiliki kepedulian untuk memakmurkan tanah.

Banyak masyarakat perdesaan yang terasing dan terpisahkan dari tanah di kampung halamannya sendiri. Hal yang lebih miris, mereka menjadi buruh di tanah nenek moyang mereka sendiri. Oleh karena itu, penelitian ini menemukan signifikansinya dalam menilisik kearifan lokal masyarakat Desa Rejoagung untuk mencipta kedaulatan tanah mereka. Kearifan lokal masyarakat Desa Rejoagung dalam menjaga tanah agar sampai dan dapat difungsikan serta dinikmati anak cucu mereka dengan hukum adat untuk tidak menjual tanah mereka keluar masyarakat desa tersebut. Hasil dan fungsi tanah benar-benar untuk mereka dan untuk anak cucu mereka. Hal ini tentu dapat dikategorikan sebagai best-practices dalam mencipta kedaulatan tanah untuk selanjutnya dapat dijadikan sebagai benchmarking, meskipun untuk menuju ke arah sana masih membutuhkan penelitian lebih lanjut dan terbukanya ruang diskursif ilmiah.

\section{DAFTAR PUSTAKA}

Achmad Caesar Luthful Hakim, S. I. P. (2021). Penerapan Pendekatan Formalistik Dalam Penemuan Hukum Adat Oleh Hakim: Studi Kasus Sengketa Surat Ket-Erangan Tanah Adat Di Kalimantan Tengah. Jurnal Agraria Dan Pertanahan, 7(1), 96. https://doi.org/10.31292/bhumi.v7i1.482

Ahmad Fadli (2016). Reinventing Government Ekowisata Kabupaten Jember. Jawa Pos, 2 September 2016.

Adair-Toteff, C. (2015). Fundamental Concepts in Max Weber's Sociology of Religion. Fundamental Concepts in Max Weber's Sociology of Religion, 4823, 1-206. https://doi.org/10.1057/9781137454799

Hasan, U., Suhermi, S., \& Sasmiar, S. (2020). Eksistensi Hak Ulayat Dalam Masyarakat Hukum Adat. Jurnal Sains Sosio Humaniora, 4(2), 649-660. https://doi.org/10.22437/jssh.v4i2.11523

Hekmatyar, V., \& Adinugraha, A. G. (2021). Ancaman Keberfungsian Sosial Pada Masyarakat Di Dalam Kawasan Konservasi: Studi Kasus Desa Ranupani Di Taman Nasional Bromo Tengger Semeru. BHUMI: Jurnal Agraria Dan Pertanahan, 7(1), 28-41. https://doi.org/10.31292/bhumi.v7i1.464

Ismi, H. (2012). Pengakuan Dan Perlindungan Hukum Hak Masyarakat Adat Atas Tanah Ulayat Dalam Upaya Pembaharuan Hukum Nasional. Jurnal Ilmu Hukum Riau, 2(02), 9056.

Nurcahyono, O. H., \& Astutik, D. (2018). Harmonisasi Masyarakat Adat Suku Tengger (Analisis Keberadaan Modal Sosial pada Proses Harmonisasi pada Masyarakat Adat Suku Tengger, Desa Tosari, Pasuruan, Jawa Timur). Diailektika Masyarakat: Jurnal Sosiolog, 2(1), 1-12.

Prasetyo, P. K., Christine, R. V., \& Sudibyanung, S. (2020). Implementasi Asas Keterbukaan pada Pengadaan Tanah bagi Pembangunan untuk Kepentingan Umum: Antara Harapan dan Kenyataan. BHUMI: Jurnal Agraria Dan Pertanahan, 6(1), 15-27. https://doi.org/10.31292/jb.v6i1.421

Sari, I. P., \& Zuber, A. (2020). Kearifan Lokal Dalam Membangun Ketahanan Pangan Petani. Journal of Development and Social Change, 3(2), 25. https://doi.org/10.20961/jodasc.v3i2.45768

Sugiyono. (2013). Metode Penelitian Pendidikan Pendidikan Kuantitatif, Kualitatif dan R\&D. Bandung: Alfabeta 
Suharto, M. P., \& Basar, G. K. (2019). Konflik Agraria Dalam Pengelolaan Tanah Perkebunan Pada Pt Hevea Indonesia (Pt Hevindo) Dengan Masyarakat Kecamatan Nanggung Kabupaten Bogor. Jurnal Kolaborasi Resolusi Konflik, 1(1), 55. https://doi.org/10.24198/jkrk.v1i1.20893

Suryawan, I. N. (2021). Memperjuangkan sumber kehidupan sesungguhnya: Masyarakat adat Dalem Tamblingan dan kedaulatan atas Alas Merta Jati di Kabupaten Buleleng, Bali. Bhumi: Jurnal Agraria Dan Pertanahan, 7(1), 79-95. https://doi.org/10.31292/bhumi.v7i1.479

Suwitra, I. M. (2014). Land Possession Rights and Its Affair.

Wahidin, S. (2017). Reformasi Agraria Dalam Perspektif Perlindungan Lingkungan Hidup. Jurnal Cakrawala Hukum, 8(1), 106-117. https://doi.org/10.26905/idjch.v8i1.1736

Zuber, A. (2019). KONFLIK AGRARIA DI INDONESIA, 8(1), 147-158. 